\title{
EFFECT OF THE INTERLEUKIN-1B -511 C/T GENE POLYMORPHISM ON THE COURSE OF DUODENAL ULCER AND EROSIVE GASTRODUODENITIS IN CHILDREN
}

\begin{abstract}
Sabid Ikhsanov ${ }^{凶}(\mathbb{D}$, Diana Sergienko (1), Marina Shtepo (D), Inna Vyazovaya (D)
\end{abstract}

Astrakhan State Medical University, Astrakhan, Russia

$\triangle$ gazken@rambler.ru tracted from whole blood samples using the standard phenol-chloroform extraction method. Genotyping of polymorphic markers of the studied gene was carried out using polymerase chain reaction and analysis of restriction fragment length polymorphism. Statistical analysis was performed using the Statistica for Windows software package.

\section{RESULTS AND DISCUSSION}

When analyzing the frequencies of the $T \backslash T$, $\mathrm{C} \backslash \mathrm{T}, \mathrm{C} \backslash \mathrm{C}$ genotypes and the $\mathrm{T}$ and $\mathrm{C}$ alleles of IL1 $\beta$ $(-511 \mathrm{c} /)$ there were no significant differences between the control and the main groups. Thus, there is no association between the $\mathrm{T} \backslash \mathrm{T}, \mathrm{C} \backslash \mathrm{T}, \mathrm{C} \backslash \mathrm{C}$ genotypes and the $\mathrm{C}$ and $\mathrm{T}$ alleles of the $\operatorname{IL} 1 \beta(-511 \mathrm{c} / \mathrm{t})$ gene polymorphism with erosive and ulcerative lesions of the gastrointestinal tract. There were no significant differences in the occurrence of $\mathrm{C} T$ alleles and $T \backslash T$, $\mathrm{C} \backslash \mathrm{T}, \mathrm{C} \backslash \mathrm{C}$ genotypes of IL1 $\beta(-511 \mathrm{c} / \mathrm{t})$ gene polymorphism in the control group and patients of the first subgroup, as well as in the control group and patients of the second subgroup $\left(\chi^{2}=0.846, \mathrm{df} 2 ; \mathrm{p}=0.655\right.$ and $\chi^{2}=3.119, \mathrm{df2} ; \mathrm{p}=0.211$, respectively).

According to the data the $T \backslash T$ genotype is predisposing to the development of duodenal ulcer in children among the cohort of patients with gastroduodenal erosions and ulcers (Table 1). According to the data it was found that patients of the first subgroup with the $\mathrm{C} \backslash \mathrm{C}$ genotype had more often a genetic predisposition than those ones with the combination of the $\mathrm{T} \backslash \mathrm{T}+\mathrm{C} \backslash \mathrm{T}$ genotypes $\left(\chi^{2}=4.221 ; \mathrm{dfl} ; \mathrm{p}=0.040\right.$; $\mathrm{OR}=4.583$ (CI 1.254-16.748)). No significant differences between the alleles in the study group were found $\left(\chi^{2} c=0.915 ; \mathrm{dfl} ; \mathrm{p}=0.339\right)$.

It was found that the $\mathrm{C} \backslash \mathrm{C}$ genotype is protective for the development of erosive gastroduodenitis in children under 12 age (Table 2) while the $\mathrm{T} \backslash \mathrm{T}$ genotype is predisposing to the development of duodenal ulcer in young children (that is up to 12 years) in relation to patients of the older age group (Table 3).

We have analyzed the effect of genotypes and alleles of $\operatorname{IL1} \beta(-511 \mathrm{c} / \mathrm{t})$ gene polymorphism on the phenotypic manifestations of diseases in the patient group (Table 4) and in isolation in children of the first and second subgroups. It was found that the $\mathrm{C} \backslash \mathrm{T}$ genotype is predisposing to a typical disease pattern 
Table 1. Distribution of genotype and allele frequencies of $I L 1 \beta(-511 \mathrm{c} / \mathrm{t})$ in children of the first and second subgroups

\begin{tabular}{|c|c|c|c|}
\hline genotype Subgroup & $D U n=46$ & $E G n=54$ & $X^{2}(d f) ; p X^{2}=5,553, d f 2 ; p=0,063$ \\
\hline $\mathrm{T} \backslash \mathrm{T}$ & $8(17,4 \%)$ & $2(3,7 \%)$ & $\begin{array}{l}X^{2}=3,762 ; d f 1 ; p=0,053 \\
\text { Fisher test } 0,04076 ; p<0,05 \\
0 R=5,474(C \mid 1,100-27,247)\end{array}$ \\
\hline$C \backslash T$ & $20(43,5 \%)$ & $24(44,4 \%)$ & $x^{2}=0,009 ; d f 1 ; p=0,923$ \\
\hline$C I C$ & $18(39,1 \%)$ & $28(51,9 \%)$ & $X^{2}=1,618 ; d f 1 ; p=0,204$ \\
\hline alleles & $n=66$ & $n=78$ & \\
\hline$T$ & $28(42,4 \%)$ & $26(33,3 \%)$ & \multirow{2}{*}{$x^{2}=1,261 ; d f 1 ; p=0,262$} \\
\hline$C$ & $38(57,6 \%)$ & $52(66,7 \%)$ & \\
\hline
\end{tabular}

Table 2. Distribution of genotype and allele frequencies of IL $1 \beta(-511 \mathrm{c} / \mathrm{t})$ gene polymorphism in children with erosive gastroduodenitis depending on age

\begin{tabular}{|c|c|c|c|}
\hline genotype age & children under 12 age $n=24$ & children over 12 years old $n=30$ & $x^{2}(d f 1) ; p$ \\
\hline$T \backslash T$ & $2(8,3 \%)$ & $0(0 \%)$ & 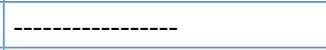 \\
\hline$C \backslash T$ & $14(58,4 \%)$ & $10(33,3 \%)$ & $X^{2}=3,375 ; d f 1 ; p=0,067$ \\
\hline$C \mid C$ & $8(33,3 \%)$ & $20(66,7 \%)$ & $\begin{array}{l}X^{2}=4,674 ; d f 1 ; p=0,031 \\
O R=0,250(C \mid 0,080-0,781)\end{array}$ \\
\hline alleles & $n=38$ & $n=40$ & \\
\hline $\mathrm{T}$ & $16(42,1 \%)$ & $10(25,0 \%)$ & \multirow{2}{*}{$x^{2}=2,566 ; d f 1 ; p=0,110$} \\
\hline$C$ & $22(57,9 \%)$ & $30(75,0 \%)$ & \\
\hline
\end{tabular}

Table 3. Distribution of genotype and allele frequencies of IL $1 \beta(-511 \mathrm{c} / \mathrm{t})$ gene polymorphism in children of the first subgroup depending on age

\begin{tabular}{|c|c|c|c|}
\hline genotype age & $\begin{array}{l}\text { children under } 12 \text { years } \\
\text { old } n=6\end{array}$ & children over 12 years old $n=40$ & $\begin{array}{l}X^{2}(d f) ; p \\
X^{2}=12,693 ; d f 2 ; p=0,002(p<0,01)\end{array}$ \\
\hline$T \backslash T$ & $4(66,7 \%)$ & $4(10,0 \%)$ & $\begin{array}{l}X^{2}=11,661 ; p<0,001 \\
O R=18,000(C \mid 2,468-131,290)\end{array}$ \\
\hline$C \backslash T$ & $0(0 \%)$ & $20(50,0 \%)$ & 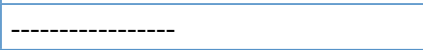 \\
\hline$C I C$ & $2(33,3 \%)$ & $16(40,0 \%)$ & $\begin{array}{l}X^{2}=0,097 ; p=0,756 \\
\text { Fisher test } 1,00000, p>0,05\end{array}$ \\
\hline alleles & $n=6$ & $n=60$ & \\
\hline$T$ & $4(66,7 \%)$ & $24(40,0 \%)$ & \multirow{2}{*}{$\begin{array}{l}x^{2}=1,588 ; d f 1 ; p=0,208 \\
\text { Fisher test } 0,38874, p>0,05\end{array}$} \\
\hline$C$ & $2(33,3 \%)$ & $36(60,0 \%)$ & \\
\hline
\end{tabular}

both in children of the main group $(\mathrm{OR}=4.352(\mathrm{CI}$ $1.841-10.292)$ and in patients with duodenal ulcer $(\mathrm{OR}=4.200(\mathrm{CI} 1.132-15.587))$ and with erosive gastroduodenitis $(\mathrm{OR}=4.583(\mathrm{CI} 1.442-14.571))$ in isolation. At the same time, the $\mathrm{C} \backslash \mathrm{C}$ genotype appears as protective $(\mathrm{OR}=0.314$ (CI 0.133-0.744)) for the development of the classic pattern of the disease and is reliably associated with the erased symptoms of the disease in children of the main group. There were no significant phenotypic differences between the $\mathrm{C}$ and $\mathrm{T}$ alleles in the pattern between patients with duodenal ulcer $\left(\chi^{2}=0.512 ; \mathrm{p}=0.475\right)$ and erosive gastroduodenitis $\left(\chi^{2}=1.257 ; \mathrm{p}=0.263\right)$.
It was found statistical differences in the frequency of the $T \backslash T, C \backslash T$ and $T \backslash T$ genotypes of IL1 $\beta$ $(-511 \mathrm{c} / \mathrm{t})$ gene polymorphism in the frequency of Helicobacter pylori in the main group and in children with duodenal ulcer. The protective effect of the $T \backslash T$ genotype on the development of HP infection in children of the first subgroup was proved $\left(\chi^{2}=20583\right.$; df2; $\mathrm{p}<0.001 ; \mathrm{OR}=3182$ (CI 0.721-14047)) (Table 5).

\section{CONCLUSION}

During the study, it was examined the effect of the IL1 $\beta-511 \mathrm{c} / \mathrm{t}$ gene polymorphism on the characters of the pattern and the course of erosive gastroduo- 
Table 4. Phenotypic variant of the set of symptoms in patients with duodenal ulcer and erosive gastroduodenitis with different alleles and genotypes of IL1ß $(-511 \mathrm{c} / \mathrm{t})$ gene polymorphism

\begin{tabular}{|c|c|c|c|}
\hline \multirow[t]{2}{*}{ genotype Diagnosis } & \multicolumn{2}{|c|}{$\mathrm{DU}+\mathrm{EG}(\mathrm{n}=100)$} & \multirow[t]{2}{*}{$\begin{array}{l}X^{2}(d f) ; p \\
X^{2}=11,863 ; d f 2 ; p=0,003\end{array}$} \\
\hline & typical $(n=38)$ & atypical $(n=62)$ & \\
\hline$T \backslash T$ & $2(5,3 \%)$ & $8(12,9 \%)$ & $X^{2}=0,979 ; d f 1 ; p=0,372$ \\
\hline CIT & $25(65,8 \%)$ & $19(30,6 \%)$ & $\begin{array}{l}X^{2}=11,810 ; d f 1 ; p<0,001 \\
O R=4,352(C \mid 1,841-10,292)\end{array}$ \\
\hline$C K$ & $11(28,9 \%)$ & $35(56,5 \%)$ & $\begin{array}{l}X^{2}=7,175 ; \text { df1 } ; p=0,008 \\
0 R=0,314(C I 0,133-0,744)\end{array}$ \\
\hline alleles & typical $(n=63)$ & atypical $(n=81)$ & \\
\hline$T$ & $27(42,9 \%)$ & $27(33,3 \%)$ & \multirow{2}{*}{$x^{2}=1,371 ; d f 1 ; p=0,242$} \\
\hline$C$ & $36(57,1 \%)$ & $54(66,7 \%)$ & \\
\hline
\end{tabular}

Table 5. Helicobacter pylori frequency in children with duodenal ulcer and erosive gastroduodenitis with different alleles and genotypes of IL $1 \beta(-511 \mathrm{c} / \mathrm{t})$ gene polymorphism

\begin{tabular}{|c|c|c|c|c|c|c|}
\hline \multirow{2}{*}{ genotype } & \multicolumn{2}{|l|}{$\mathrm{DU}+\mathrm{EG}$} & \multicolumn{2}{|l|}{ DU } & \multicolumn{2}{|l|}{ EG } \\
\hline & identified $n=25$ & not identified $n=75$ & identified $n=9$ & not identified n=37 & identified $n=16$ & not identified $n=38$ \\
\hline $\mathrm{T} \backslash \mathrm{T}$ & $6(24,0 \%)$ & $4(5,3 \%)$ & $6(66,7 \%)$ & $2(5,4 \%)$ & $0(0 \%)$ & $2(5,3 \%)$ \\
\hline CIT & $8(32,0 \%)$ & $36(48,0 \%)$ & $0(0 \%)$ & $20(54,1 \%)$ & $8(50,0 \%)$ & $16(42,1 \%)$ \\
\hline$C K$ & $11(44,0 \%)$ & $35(50,7 \%)$ & $3(33,3 \%)$ & $15(40,5 \%)$ & $8(50,0 \%)$ & $20(52,6 \%)$ \\
\hline$x^{2}(d f) ; p$ & \multicolumn{2}{|l|}{$\begin{array}{l}X^{2}=7,653 ; \text { df } 2 ; \\
p=0,022\end{array}$} & \multicolumn{2}{|c|}{$\begin{array}{l}X^{2}=20,583 ; d f 2 ; \\
p<0,001 \\
O R=3,182(C \mid 0,721-14,047)\end{array}$} & \multicolumn{2}{|l|}{$\begin{array}{l}X^{2}=1,015, \mathrm{df} 2 \\
p=0,602\end{array}$} \\
\hline alleles & identified $n=33$ & not identified $n=111$ & identified $n=9$ & not identified $n=57$ & identified $n=24$ & not identified $n=54$ \\
\hline$T$ & $14(42,4 \%)$ & $40(36,0 \%)$ & $6(66,7 \%)$ & $22(38,6 \%)$ & $8(33,3 \%)$ & $18(33,3 \%)$ \\
\hline C & $19(57,6 \%)$ & $71(63,9 \%)$ & $3(33,3 \%)$ & $35(61,4 \%)$ & $16(66,7 \%)$ & $36(66,7 \%)$ \\
\hline$X^{2}(d f) ; p$ & \multicolumn{2}{|c|}{$x^{2}=0,443 ;$ df $1 ; p=0,506$} & \multicolumn{2}{|c|}{$x^{2}=1,490 ; d f 1 ; p=0,223$} & \multicolumn{2}{|c|}{$X^{2}=0,068, d f 1 ; p=0,795$} \\
\hline
\end{tabular}

denitis and duodenal ulcer in children. It is proved that the $T \backslash T$ genotype is predisposing for the development of the duodenal ulcer and is associated with the onset of the disease at an early age and HP infection. Associations of the $\mathrm{C} \backslash \mathrm{T}$ genotype with a typical phenotype of diseases were identified while the $\mathrm{C} \backslash \mathrm{C}$ genotype is associated with a high significance of the genetic factor in the development of the disease. Thus, the study of the genotypic basis of duodenal ulcer and erosive gastroduodenitis in children is an important task, the solution of which will promote the development of fundamental ideas about the pathogenesis of the disease and the formation of a personalized approach to treating patients.

\section{REFERENCES}

1. Shaimardanova E.Kh., Nurgalieva A.KH., Nadyrshina D.D., KhUSNUTDinova E.K.

Molecular genetic aspects of duodenal ulcer. Medical genetics. 2014; 13 (11): 4-14.
2. Arisawa T., Tahara T., Shibata T. et al. Association between genetic polymorphisms in the cyclooxygenase-1 gene promoter and peptic ulcers in Japan. International journal of molecular medicine. 2007; 20(3): 373-378 